欧州ブドウの食味を持ち，栽培容易な大粒ブドウ品種「シャインマスカット」の 育成

農研機構果樹茶業研究部門ブドゥ「シャインマスカット」育成グループ（代表 山田昌彦）

農研機構・果樹茶業研究部門・ブドウ・カキ研究拠点, 広島県東広島市, $\overline{7} 739-2494$

\title{
Development of a table grape cultivar 'Shine muscat', which can be easily grown in wide areas in Japan, and has big berries with the eating quality specific to superior European table grape cultivars
}

\author{
'Shine muscat' grape breeding group in Institute of Fruit Tree and Tea Science, National Agriculture and Food Research \\ Organization (Representative; Masahiko Yamada)
}

Grape and Persimmon Research Station, Institute of Fruit Tree and Tea Science, National Agriculture and Food Research Organization, Higashihiroshima, Hiroshima 739-2494

キーワード

品種, ブドウ, 耐病性, 種なし, 肉質, マスカット, Vitis

\section{1. はじめに}

生食用ブドウは欧州ブドウと米国ブドウに大別される. 日本では，明治以降，多くのブドウ品種が海外から導入 されたが，降雨の多い気候のため，欧州ブドウは病害と 裂果が多発して栽培が困難であった。そして, 比較的病 害に強く裂果も発生しにくい「デラウェア」,「キャン心゙ ルアーリー」などの米国ブドウが普及した（菊池 1948）.

米国ブドウは，一般に果粒が小さく，噛み切りにくい 肉質で，特有のフォクシ一香を持っている（Sato et al. 1997)。世界で米国ブドウが普及している地域は, 欧州ブ ドウの栽培が困難な地域である。一方，優良な生食用欧 州ブドウ品種は噛み切りやすくて硬い肉質とマスカット 香を持って扸（Sato et al. 1997），日本でも大きな消費 需要があると考えられる.

日本では米国ブドウと欧州ブドウの交雑による育種が 行われ,「巨峰」,「マスカットベーリーA」,「ピオーネ」 などが育成されて広く普及した（Yamada and Sato 2016）。 しかし, これらの品種の肉質は両種の中間的で, 香りも フォクシー香である.

現在の日本では，欧州ブドウは降雨の少ない地方や降 雨を避けた施設下で栽培されている．欧州ブドウに分類 されてきた「甲州」は，最近，欧州ブドウと東アジア原

2018 年 10 月 15 日受領 日本育種学会賞受賞 (第 138 号) 2018 年 11 月 8 日 J-STAGE 早期公開

Correspondence: yamada.masahiko@nihon-u.ac.jp
産ブドウ野生種を祖先に持つ雑種と推定された（GotoYamamoto et al. 2015).「甲州」を除く欧州ブドウの栽培 面積は, 生食用全ブドウ栽培面積の 4\%程度である（農 林水産省 2017).

\section{2. 育成経過}

農林水産省果樹試験場（現 農研機構果樹茶業研究部 門）では，ブドウの消費を拡大するには，優れた生食用 欧州ブドウ品種の食味を持つとともに，米国ブドウのよ らに耐病性・耐裂果性を持ち，栽培容易なブドウ品種の 育成が必要と考光, 長期的戦略の下, 欧州ブドウと米国 ブドウの交雑による育種を進めた（山田ら 2008，2017, Yamada and Sato 2016).

農林水産省果樹試験場安芸津支場（育成地）では，欧 米雑種の交雑実生個体から, やや大粒で, 噛及切りやす く硬い肉質を持つ安芸津 21 号を選抜し，これに様々な大 粒の欧州ブドウを交配した（山田ら 2017）。「シャインマ スカット」は，1988 年に安芸津 21 号に欧州ブドウの「白 南」を交配して得た交雑実生から選抜された二倍体の品 種である（図 1, 山田ら 2008）。

1993 年に予備選抜および 1997 年に一次選抜し，1999 年より 28 都道府県 30 か所の国公立試験研究機関で系統 適応性検定試験（系適試験）を行い，2003 年に新品種と なった（山田ら 2008）。2003 年にブドウステムピッティ ング随伴ウイルスを検出することが可能となり，「シャイ ンマスカット」試験樹に拈いても感染が確認された。 そ 


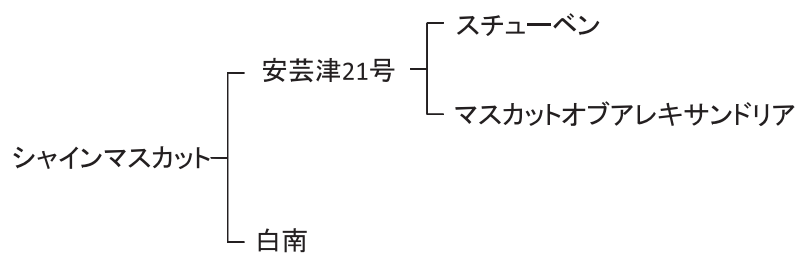

図 1.「シャインマスカット」の系譜.

こで, 3 年の歳月をかけて無毒化して母樹を確立し, 2007 年に苗木生産者に穂木を供給して苗木生産を開始した。

\section{3. 特 性}

「シャインマスカット」は「優れた生食用欧州ブドウの 食味を持ち, 而病性が比較的強くて栽培しやすく, 種な し栽培できる大粒の黄緑色品種」である（山田ら 2008）. 肉質は噛及切りやすくて硬く, マスカット香がある。 、 スカット香を持つ品種の栽培面積は少なく,「シャインマ スカット」以外のマスカット香の品種の栽培面積は生食 用全ブドウ栽培面積の $1 \%$ 以下である(農林水産省 2017). 「シャインマスカット」の果皮は厚くなく，渋みがないた め, 皮ごと食べられる。優良な生食用欧州ブドウと同様 の肉質であるが，欧州ブドウで発生しやすい裂果は一般 に発生せず, 縮果症は発生しにくい, 糖度は高く, 酸味 は低い.「巨峰」より脱粒しにくく，日持ちが長い。

大粒で，ジベレリン処理により種なし栽培できる。安 定して完全に種なしとするには，開花前にストレプトマ イシン剤を散布する（山田ら 2008）。現在では, 着粒安 定と大粒化のため，フルメット液剤を処理することが多 い.

べと病拈よび晚腐病抵抗性は「巨峰」なみに強いと評 価された（Shiraishi et al. 2007, 山田ら 2008）。黒とう病 には強くなく（Kono et al. 2013）, 降雨の多い地域ではビ ニル被覆による雨よけ栽培が必要である。花穂整形掞よ び摘粒労力は「巨峰」の種なし栽培と同程度と評価され た（山田ら 2008）。省力的な剪定である短梢剪定が可能 で，収量性は四倍体の「巨峰」より高い，

全国の系適試験では「シャインマスカット」は東北地 方南部以南の「巨峰」栽培地域で栽培できると評価され た（山田ら 2008）。岩手県農業研究センター（北上市） に抢ける試験栽培では「シャインマスカット」の耐寒性 は「巨峰」と同程度と評価された。東北地方など冷涼な 地域では, 温暖な地域と比べ, ブドウの成熟は遅く, 酸 含量は高い。「シャインマスカット」の果実成熟期は「巨 峰」に近い時期で，酸含量は「巨峰」より低いため，冷 涼な地域でも「巨峰」の栽培地域では栽培可能と見込ま れる。

\section{4. 普及状況および育種への利用}

「シャインマスカット」は苗木販売開始以降，急速に栽 培面積が拡大し，2015 年には全ブドウ栽培面積の 7\%に あたる 992 ha に達し,「巨峰」,「デラウェア」,「ピオー ネ」に次ぐ 4 位となった（図 2, 図 3)。栽培地域は, 長 野, 山梨，岡山など全国 41 都道府県に広がっている.

栽培面積の拡大に伴い生産量も増加しているが，その 品質の評価が高いことから卸売価格は「巨峰」の 2 倍近 い価格で推移して沶り（東京都中央卸売市場統計情報 2017), 生産農家の収益性は高い.

日本農業新聞が発表した「果物売れ筋トレンド（スー パーマーケット，果実専門店，卸売会社，生協などを対 象にした調查)」で，様々な果物を含む約 200 アイテム中 「シャインマスカット」は「売れ筋期待值」が 6 年連続で 第 1 位にランクされるなど,「シャインマスカット」の需 要は非常に高い（山田ら 2017）.

また「「シィンマスカット」を片親とした交雑育種が 民間拈よび公立試験研究機関で進んだ。各県および民間 育種家のホームページ，苗木生産業者の販売カタログに よると，これまでに 12 品種以上が育成されたと考光られ る.

\section{5. 栽培・流通技術開発研究と普及}

「シャインマスカット」が育成されてからのち，農研機 構，公立試験研究機関，大学などで，普及に資する多く の研究が取り組まれた.

生理障害発生対策，貯蔵技術，花穂整形方法による商 品性向上技術，大粒化 - 着粒安定技術，成熟期判定技術， 適正着果量の解明，剪定・仕立て技術，土䁃水分管理技 術, 施設栽培技術, 各地飞扮ける適応性の解明, 各種加 工品の開発と多岐に及んでいる。農研機構はこれらの研

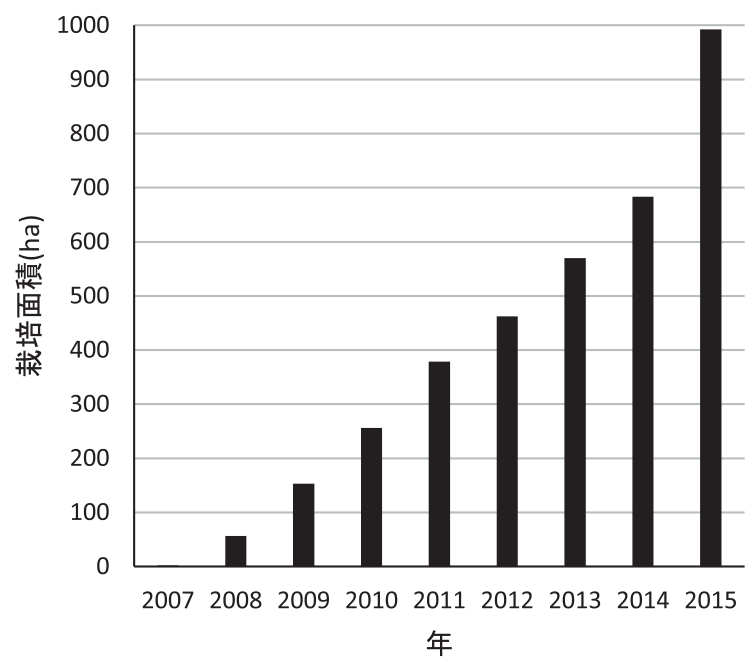

図 2.「シャインマスカット」の栽培面積の推移（農林水産省特 産果樹生産動態等調査による)。 


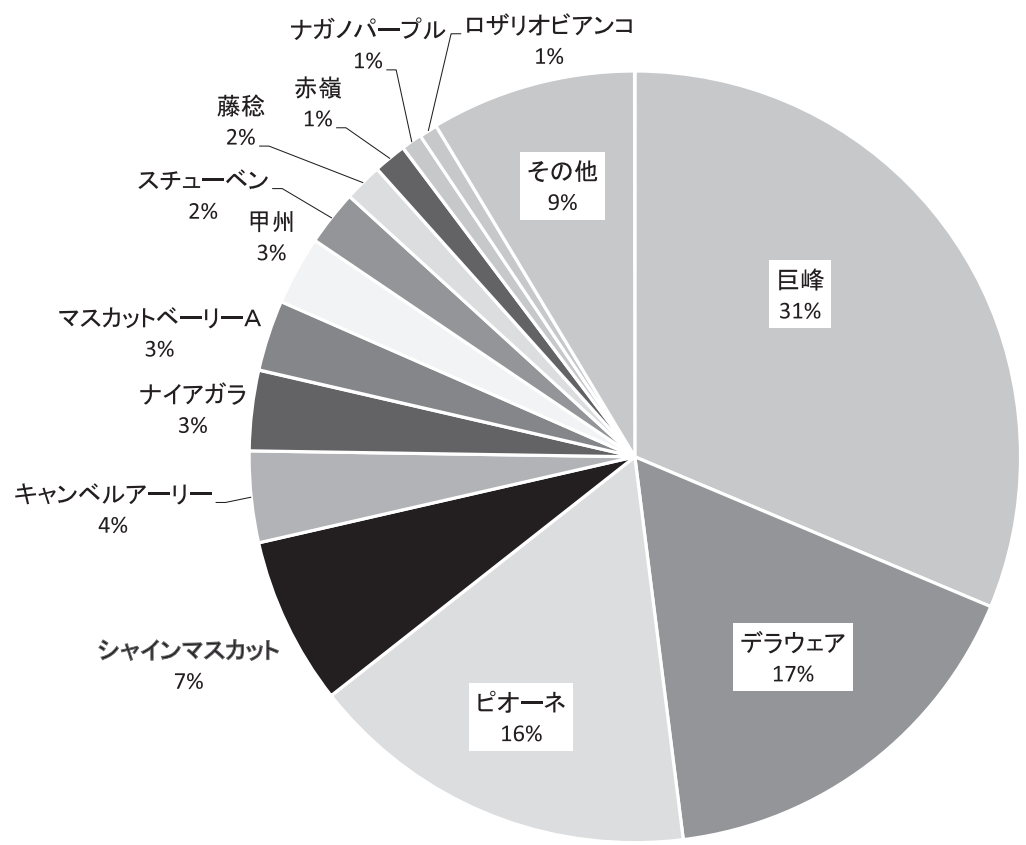

図 3. 全国ブドウ栽培面積の品種別割合（2015）（農林水産省平成 27 年産特産果 樹生産動態等調査による).

究成果の 80 情報をホームページで公表している（山田ら 2017). 園芸学会文献データベースでも「シャインマス カット」に関し，園芸学会大会研究発表を中心に 54 報が 記録されている（山田ら 2017）。

「シャインマスカット」は農研機構で長期をかけて育成 した品種であるが，全国の国公立試験研究機関の協力体 制のもと，特性・地域適応性の解明，栽培・流通技術開 発と普及が取り組まれてきた。その結果，急速に普及が 進んでいる，日本全体の品種開発・普及のため，このよ らな体制の維持・発展を期待したい.

\section{謝 辞}

系適試験に参画された公立試験研究機関，育種をサ ポートされた戋場管理職員・事務職員を始めとする農研 機構の多くの方々，普及に尽力されている多くの方々に 深く感謝申し上げる。

\section{農研機構果樹茶業研究部門ブドウ「シャインマ スカット」育成グループ}

山田昌彦, 山根弘康, 佐藤明彦, 平川信之, 岩波 宏,
吉永勝一，小澤俊治，三谷宣仁，白石美樹夫，吉岡美加 乃, 中島育子, 中野正明, 中畧良二

\section{引用文献}

Goto-Yamamoto, N., J. Sawler and S. Myles (2015) PLoS ONE 10: e0140841.

菊池秋雄（1948）果樹園芸学（上）, 養賢堂, 東京. 259-312.

Kono, A., A. Sato, Y. Ban and N. Mitani (2013) HortScience 48: 1433-1439.

農林水産省 (2017) 平成 27 年産特産果樹生産動態等調査. [http:// www.maff.go.jp/j/tokei/kouhyou/tokusan_kazyu/index.html].

Sato, A., H. Yamane, N. Hirakawa, K. Otobe and M. Yamada (1997) Vitis 36: 7-10.

Shiraishi, M., M. Koide, H. Itamura, M. Yamada, N. Mitani, T. Ueno, R. Nakaune and M. Nakano (2007) Vitis 46: 196-200.

東京都 (2017) 東京都中央卸売市場統計情報. [http://www.shijoutokei.metro.tokyo.jp/].

山田昌彦・山根弘康・佐藤明彦・平川信之・岩波 宏・吉永勝 一 一小澤俊治・三谷宣仁・白石美樹夫・吉岡美加乃ら（2008） 果樹研報 7: 21-38.

Yamada, M. and A. Sato (2016) Breed. Sci. 66: 34-45.

山田昌彦・山根弘康・佐藤明彦（2017）園芸学研究 16: 229-237. 